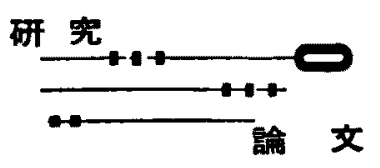

\title{
801. 高温カス炉用黒鉊材料の切欠き感度
}

\author{
川上 春 雄* \\ (1984年 6 月 18 日受理) \\ (1984年 8 月13日 再受理)
}

Notch Sensitivity of Graphite Materials for VHTR

By Haruo KAWAKAMI

\begin{abstract}
Notch effects on strength were investigated for IG-11 and PGX graphite, which were promising materials for core structures of an experimental VHTR in Japan. Notch sensitivity in tensile strength tests decreased as notch radius decreased. Notch sensitivity of IG-11 was higher than that of PGX. Compressive fracture of PGX was in a shear mode, while that of IG-11 was in a mixed mode of shear and transverse splitting. Compressive strength of IG-11 specimens with transverse slits was smaller than that of smooth specimens, which suggested that a shear mode fracture preceded an ultimate transverse splitting. Results of water quenching tests showed that thermal shock fracture resistance of IG-11 could be smaller than that of PGX when a notch with small radius existed.
\end{abstract}

KEYWORDS: VHTR reactors, graphite, tensile strength, compressive strength, thermal stresses, water quenching, thermal shock fracture resistance, notches, impact tests

\section{I. 粕言}

現在日本原子力研究所で計画されている高温がス実 験炉の炬内構造は汪とんど黑鉛ブロックで搆成されて いる。黑鉛はガス冷却型原子灯の隇速材, 構造材とし て古くから実績のある材料であり，その強度特性につ いても多くの報告がなされている(1122)。しかし黒鉛の 破堎のメカニズムは金属材料に比して特異な点が多 くそそのすへでが明確にされているわけではない。

材料に切欠きがある場合の応力集中特性を表わす切 久感度は，黑鉛構造物の形状を決定する際に重要な

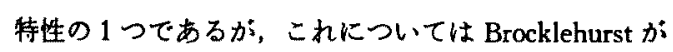
ギルッナイト系黒鉛のIM 1-24について報告している たけで(3)，その他の報告例は少ない上らである。特に 高温ガス実験炉の有力候補銘柄であるIG-11 と PGX については未だ報告例がない。

著者は, 上記の $2 つ の$ 銘柄について, 均一引張り応

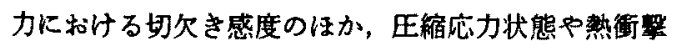
負荷時における切欠きの効果を検討しだ。本報はそれ
らの結果を報告するものである。

\section{II. 実験方法}

\section{1. 実験材料}

実跲に用いた黒鉛銘唡は，国産の微粒等方性黒鉛の IG-11，米国産の败粒等方性黒鉛 Stackpole 2020 (SP 2020)捄よび米国産のモールド成形異方珄黑鉛 PGX の 3 種類である。たたし，主な実験はIG-11 と PGXに ついて行い，SP 2020 は後述する水中急冷試験でのみ 使用した。

\section{2. 实跙方法}

㬰験項目をTable 1 に，それぞれの試験片形状を Fig.1に示す。

引張り試験と王縮試験は，それぞれFig. 1(a)，(b)に示 すような切欠きを試験片に設けて，切欠きのない平滑 試験片と比較して切欠き㚳果を検討した。特に圧縮試 験においては，切欠き圧縮方向に対して平行と垂直の

* 稫士䉓総合研究所(Fuji Elec. Corporate Res. \& Develop., Ltd.) 
Table 1 Scope of experiments

\begin{tabular}{lcc}
\hline & Notch radius & Material \\
\hline Tension & no notch & IG-11 \\
& $5 \mathrm{~mm}$ & PGX \\
& $2 \prime \prime$ & \\
& $0.5 \prime \prime$ & \\
\hline Compression & no notch & IG-11 \\
(transverse slit) & $2 \mathrm{~mm}$ & PGX \\
& $1 / \prime$ & \\
& $0.5 \prime \prime$ & IG-11 \\
\hline Compression & no notch & \\
(parallel slit) & $2 \mathrm{~mm}$ & \\
& $1 / \prime$ & IG-11, PGX \\
& $0.5 \prime \prime$ & Stack pole 2020 \\
\hline Water quench & $0.5 \mathrm{~mm}$ & \\
& &
\end{tabular}

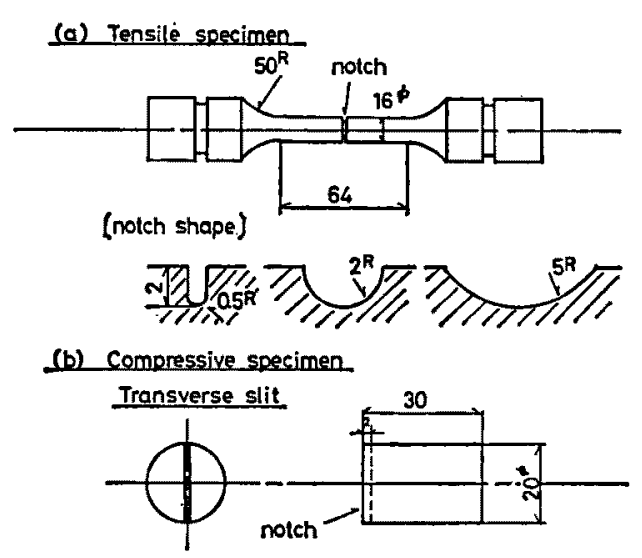

Parallel slit

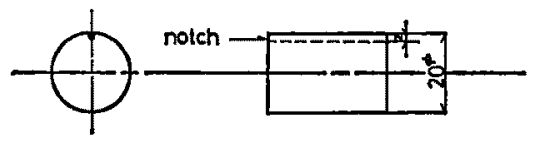

(notch shape)

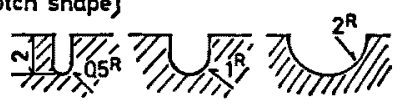

(c)' Woler quenching specimen

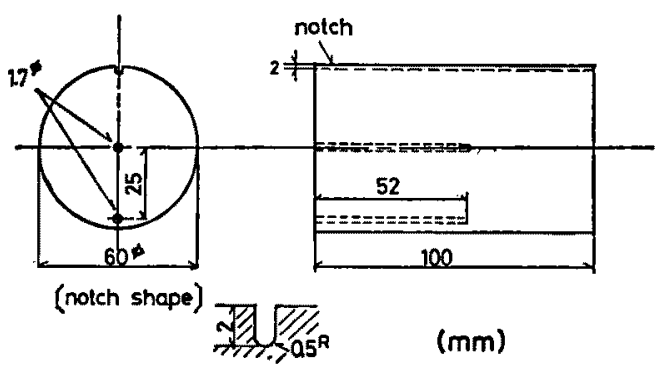

Fig. 1 Shape of specimens
2 種類とした。試験は室温で行い,歪み速度は引張り試

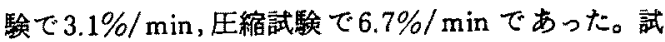
験片数は各条件について 5 個ずつとした。また，異方 性のある PGX 黒鉛については，主として負荷方向と モールド成形方向が同しになるよらに試験を行なっ た。

水中急冷試験は，試料をテッ素ガス中で加熱して所 定の温度で安定させた後，水中へ投入して急冷するこ とにより試験片に熱怘力を発生させ，これによる試験 片の割れ発生の有無を調べたものである。水温は約10

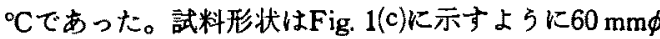
$\times 100 \mathrm{~mm}$ の冈柱状であり，温度測定用熱電対 $(1.6 \mathrm{~mm} \phi$ のシース型)を挿入するための $1.7 \mathrm{~mm} \phi$ の小孔を $2 つ$ 設けたものである。切欠きとして先端曲事半径 0.5 mmのスリットを軸方向に入れたものと入れないもの の兩方について試験を行なった。

炬内で黒鉛に発生する応力はほとんど2 次応力であ り，特に熱视力が最も大きいと予想される。しかし炉 内の熱応力は定常温度分布に起因するものであり，上 記のよらな急冷試験で発生する熱応力とは試験片内の 応力分布等は異なっている。それにるかかわらず上記 試験を行なったのは，材料の熱応力抵抗を示す熱衝媻 破壊抵抗保数が定常温度分布の場合と急冷の場合で同 じであり，熱膨脹率ヤング率等の諸物性值の温度変 化も含んだ材質の相対比較試験として有効であると考 えたためである。

\section{III. 実験 結 果}

\section{1. 引張り試験}

Table 2 に引張り試験に扰㚈る破断強度を示す。切 欠きのある試験片の破断强度は切欠きのない場合に比 して低くなっておう，これは応力集中によるるのと考 えられる。

Table 2 Results of tensile tests

(Unit: $\mathrm{kg} / \mathrm{cm}^{2}$ )

\begin{tabular}{lcccc}
\hline \multirow{4}{*}{ Materials Notch radius } \\
\cline { 2 - 5 } & No notch & $5 \mathrm{~mm}$ & $2 \mathrm{~mm}$ & $0.5 \mathrm{~mm}$ \\
\hline IG-11 & $254 \pm 25$ & $187 \pm 26$ & $134 \pm 9$ & $97 \pm 10$ \\
$\mathrm{PGX}(/)$ & $75.8 \pm 0.8$ & $47.0 \pm 5.2$ & $50.4 \pm 12.2$ & $43.3 \pm 4.8$ \\
$\mathrm{PGX}(\perp)$ & $71.2 \pm 8.8$ & - & - & - \\
\hline
\end{tabular}

Fig. 2 は，Peterson による連続弾性体の半円形環状

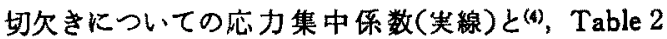
の結果から算出した応力集中係数(破線)を比较したり のである。一般に応力集中保数は，切欠き先端の曲率 


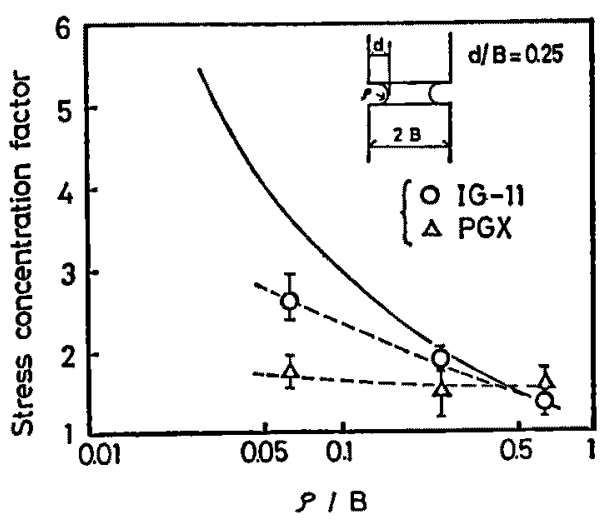

Full line curve is derived from Peterson's results ${ }^{(4)}$.

Fig. 2 Stress concentration factor of graphite materials observed in tensile tests

半径が小さいほど增加する傾向にあるが，本実験で得 られた黒鉛では, 連続弾性体に比してその程度は小さ く、特に PGX のそれははとんよ变化していなかった。 応力集中特性は試験片のいくつかの形状バラメータ （切久き長さ，切久き先端曲率半径，試験片りガメント 等)に依存するが，Tuckerは黒鉛の平板二重切久試 験片について解析を行い，次式で定義する切欠き感度 保数が，主として切欠き先端曲率半径化存すること を示した(5)。

切欠き感度倸数

$=\frac{\text { (応力集中保数貺定値) }}{\text { (欠楩のな、彈性体の応力集中係数計算値) }}$

$$
\text { たたし， }
$$

忍力集中係数測定值 $=\frac{\text { (平滑試駼片の强度) }}{\text { (切欠き試駼片の强度) }}$

Fig. 3 は，(1)式で定義された切欠き感度俰数を Fig. 2 の結果より算出しこれと切欠き先端曲率半径 との関係を示したものである。切欠き感度係数は， 切欠き先端曲率半径が小さくなると低下する傾向があ る。また，IG-11 の切欠き感度は PGXに比して高い ことがかかる。

PGX の切欠き先端曲率半径 $5 \mathrm{~mm}$ の切欠感度係数 が1.0より大きくなっている理由としては，(1)応力集 中保数を算出する際, 平滑試験片の強度として直径16 $\mathrm{mm}$ の試験片のるのを用いたが，切欠さ先端曲率半径 が大きくなった極限は直径12 mmであり, 両者の強度 が体積効果により異なったとか，(2)試験片数が各条件 5 本と比較的少なかったためのデータのバラッキとか が考えられる。

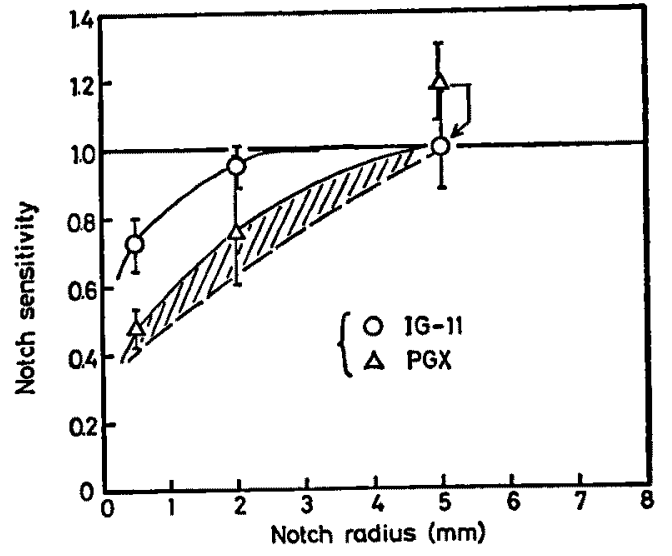

Hatched zone is an estimated zone for PGX assuming that notch sensitivity is 1.0 when notch radius is $5.0 \mathrm{~mm}$.

Fig. 3 Relation of notch sensitivity with notch radius for IG-11 and PGX

このうち(1)は，試験片の寸法か黑鉛粒径比して十 分大きくない場合には, 引張り強度は試験片寸法の減 少ととむに低下することが知られており枋，PGX の場 合む直径 $12 \mathrm{~mm}$ の試験片の引張り強度が直径 $16 \mathrm{~mm}$ の 場合に比して小さい可能性が考えられるといらことで ある。これを检討するため製造ロットの異なる PGX について直径12と $16 \mathrm{~mm}$ の試験片について各10本の試

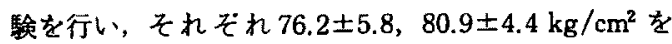
得た。直径 $12 \mathrm{~mm}$ の方がわずかに小さな值を示してい るすのの有意の差は認められずこれにより先端曲率 半径 $5 \mathrm{~mm}$ の切欠き感度保数が1.0より大きいのはデー タのバラッキによると考克られる。

バラッキの要因としては，5 $\mathrm{mm}$ 切欠き試験片の強 度と平滑試験片の強度が考光られる。仮に $5 \mathrm{~mm}$ 切久 き試駼片の切久き感度保数を1.0とした場合，0.5，2.0 $\mathrm{mm}$ 切欠き試験片の切欠き感度係数としては，直径 $16 \mathrm{~mm}$ の平滑試験片のデータを用いて算出する方法と， $5 \mathrm{~mm}$ 切久き試験のデータから直径 $12 \mathrm{~mm}$ の平滑試験 片を推算して用いる方法とが考えられる。Fig. 3 では 前者を実線,後者を破線で示した。実際のデータは両 方の線の間の斜線部にあると思われるが，体皘効果む 若千あることを考えると，どちらかといえば破線に近 いと考兄られる。以上から以下の考察では便宣上，破 線のデータを用いた。

\section{2. 代樎試弱}

Fig. 4 亿試験片の破断強度，Fig. 5 亿破断した試料 の外観を示す。压縮方向に垂直なスリット（横スリッ ト)を入れた陚験片の破断強度は, スリットの入った 

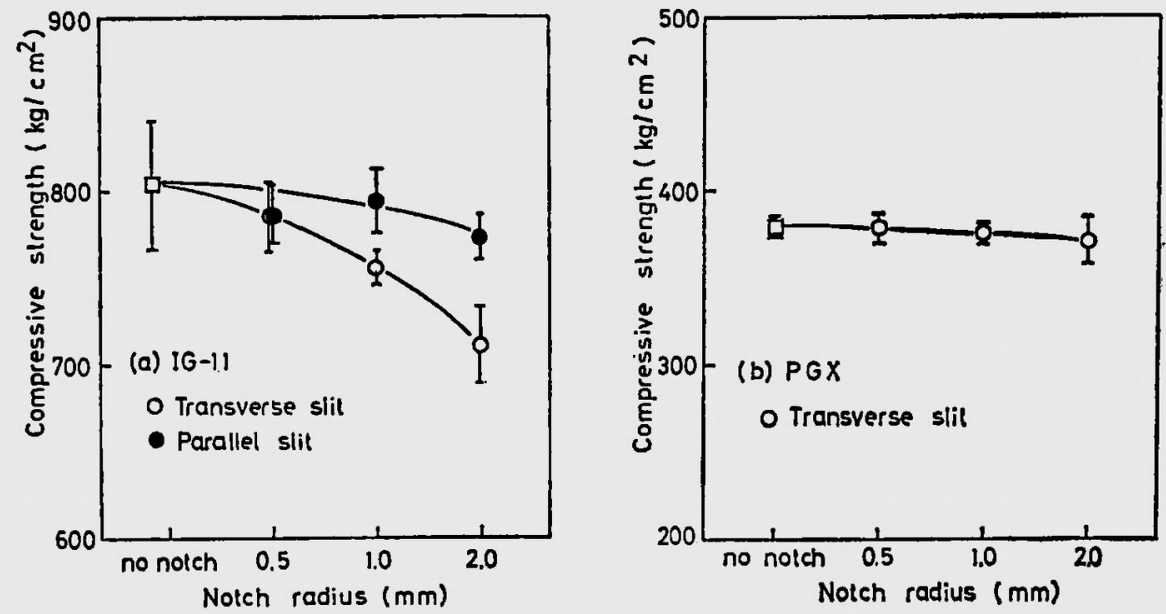

Fig. 4 Relation of compressive strength with notch radius

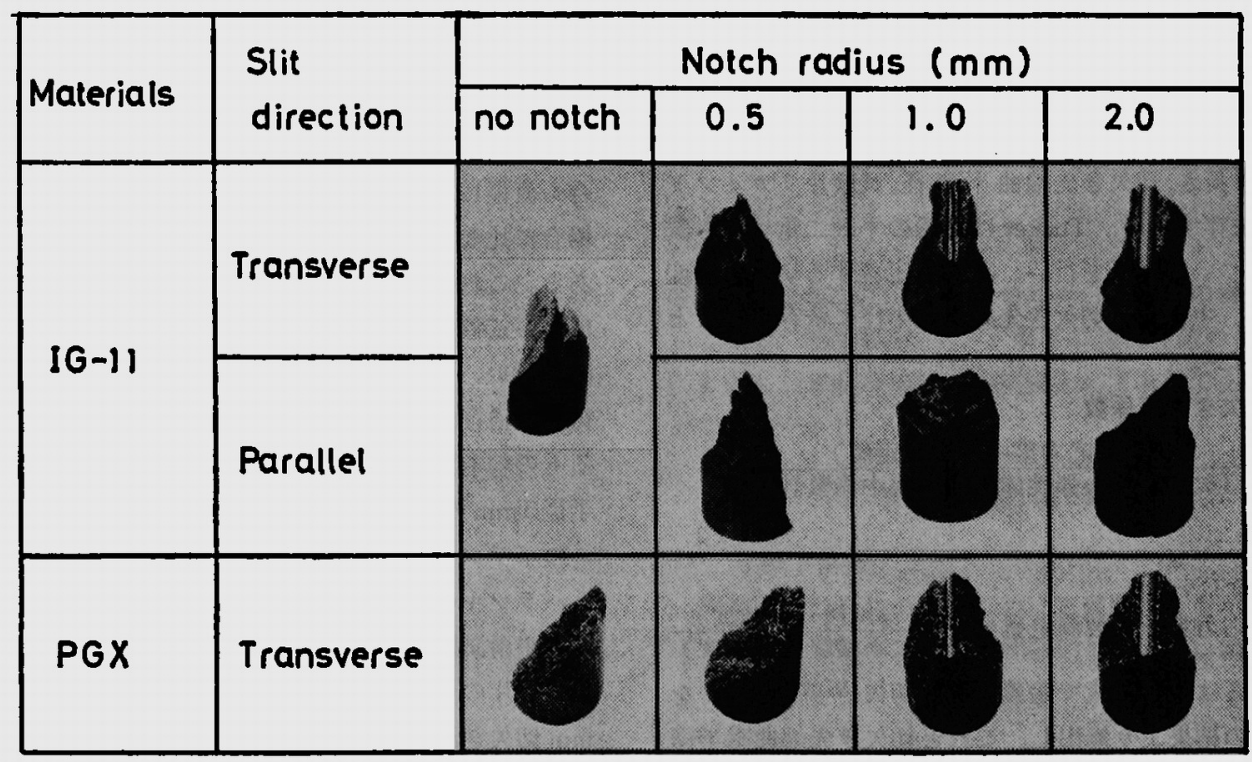

Fig. 5 Outview of compressive specimens

部分の最小断面積をむとに算出した。

PGX の場合，横スリットを入れても破断強度はほ とんど変わらなかった。破断モードはすべて，破面が 圧縮方向に対し $30 \sim 40^{\circ}$ の角度を持つ㓞断モードであ ったが，切欠きのない試験片と切欠き先端曲率半径 $0.5 \mathrm{~mm}$ の試験片とでは破面が武験片端から生じた 1 つの面であるのに対し，切欠き先端曲率半径が 1,2 $\mathrm{mm}$ の試験片ではスリットの両側面から2つの破面の 形成が認められた。Photo. 1 (a)，(b)には破断試料の破 面を示す。玨縮破壤した試料はすべて Photo. 1 (b)に示
すよらな韵断すべり形態を示しており，Photo. 1 (a)に 示す引張り破壊で見られる粒界破面は認められなか った。

IG-11 の場合, 平滑試験片に比して横スリットを入 れた試験片の破断強度は低下しており，特に先端曲率 半径の大きい試験片ほど強度の低下が大きかったか， 縌スリットを入れた試験片の破断強度は平滑試験片と ほとんど変わらなかった。

IG-11 の破面は，試験片の長さ30 $\mathrm{mm}$ のちち2 10 $\mathrm{mm}$ を占める竘断破壊破面と残りの部分を占める珐縮 

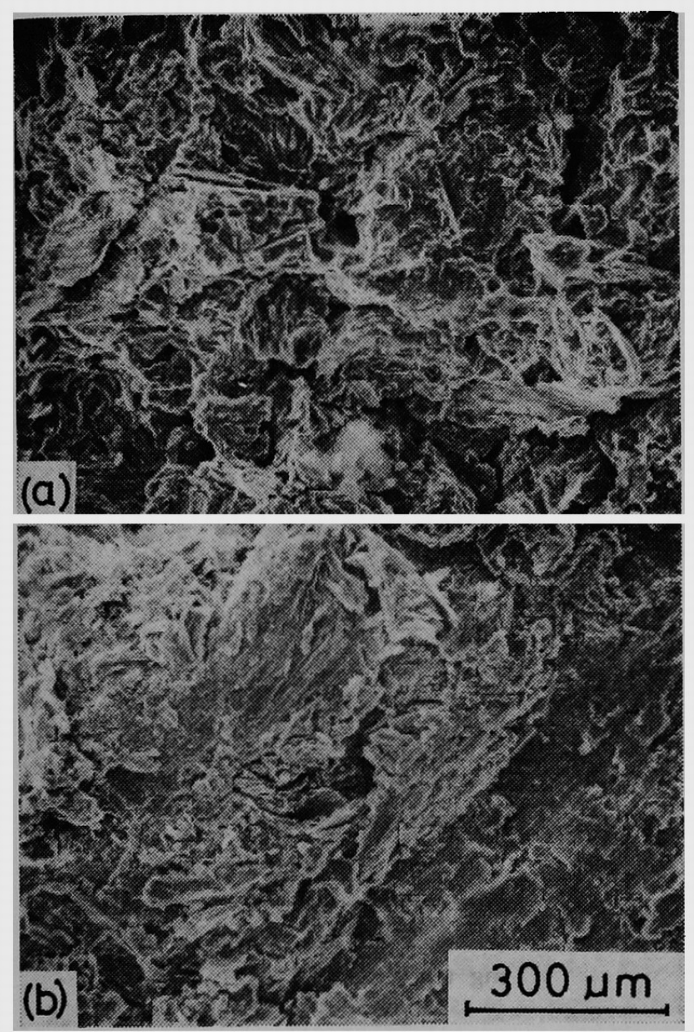

(a) Tensile spocimen

(b) Compressive specimen (shear)

Photo. 1 Fractograph of PGX specimens

負荷方向にほほ平行な破面(縦割れ破面)との混合形態 であった。

Photo. 2 (a)〜(c)にはそれらの破面形態を示す。王縮 破壊で生じた縋割れ破面は引張り破壊破面と類似した 形態を示しており，これが圧縮負荷方向に垂直な引張 り応力により生じたことを示唆している。実際, 先端 曲率半径 $0.5,1.0 \mathrm{~mm}$ の横スリットを入れた試験片で は、スリット先端から圧縮負荷方向に割れが発生して いるケースが多く認められた。しかしこれらのスリ ット先端からの割れは多くの場合試料の内部で停止し ており，試料の最終的破断はスリット側部から生じた 岦断破面とそれに連なる綎割れ破面に関与している場 合がほとんどであった。

\section{3. 水中急冷試験}

水中急冷時の代表的な冷却曲線をFig. 6 に，また 2 つの温度計測点の最大温度差と䄯温温度との関係を Fig. 7 に示す。最大温度差は銘柄によってあまり差が 認められなかった。

水中急冷により試験片には割れを生じたるのがあっ
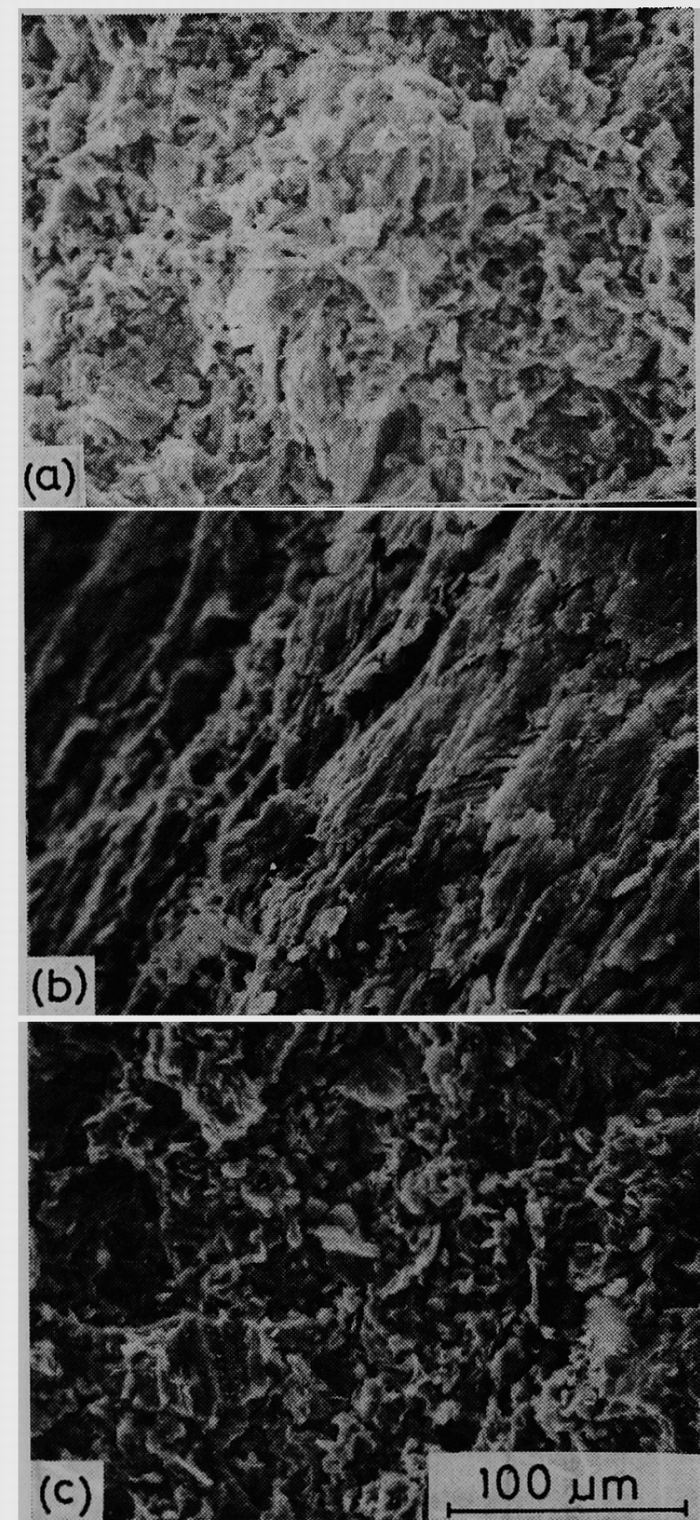

(a) Tensile specimen

(b) Compressive specimen (shear)

(c) Compressive specimen (transverse splitting)

Photo. 2 Fractograph of $\mathrm{IG}-11$ specimens

た。Fig. 8 に各昇温温度における割れ発生の有無を,

Fig.9には代表的な割れ発生位膡を示した。スリット のある試験片ではスリットから、スリットのない試験 片では温度計湘用の小孔から割れが生してている場合が 多かった。

割れ発生のための限界昇温温度は，スリットがある 


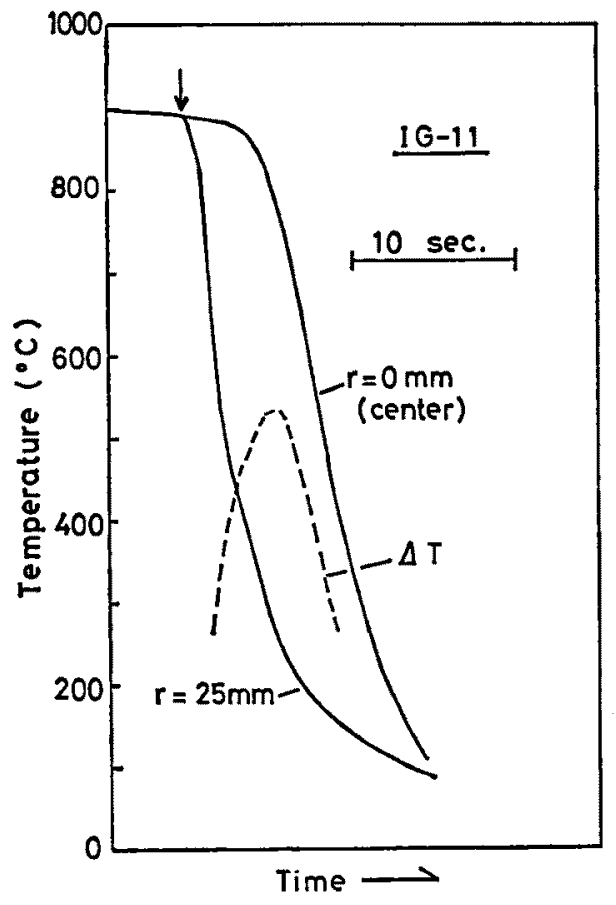

Temperature difference $\Delta T$ is shown in a dotted line. An arrow mark indicates an instance of an injection of a heated specimen into water.

Fig. 6 Temperature transient curves in water quenching test of IG-11

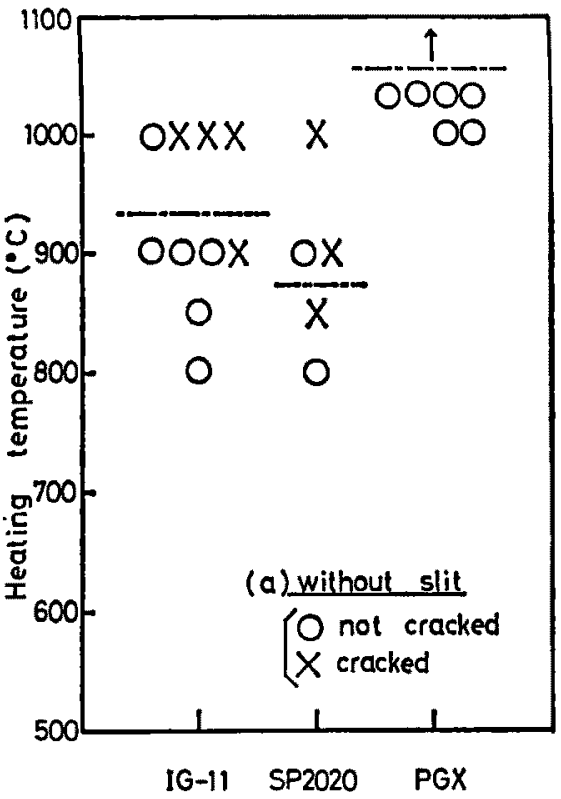

場合は IG-11, SP 2020 とも約 $600^{\circ} \mathrm{C}$ ，スリットがない 場合はIG-11 で900 1,000 $\mathrm{C}, \mathrm{SP} 2020$ で850 900 ${ }^{\circ} \mathrm{C}$ あったが，PGXではスリットの有無にかかわらず 1,030 Cからの急冷です割れの発生は認められなかっ た。

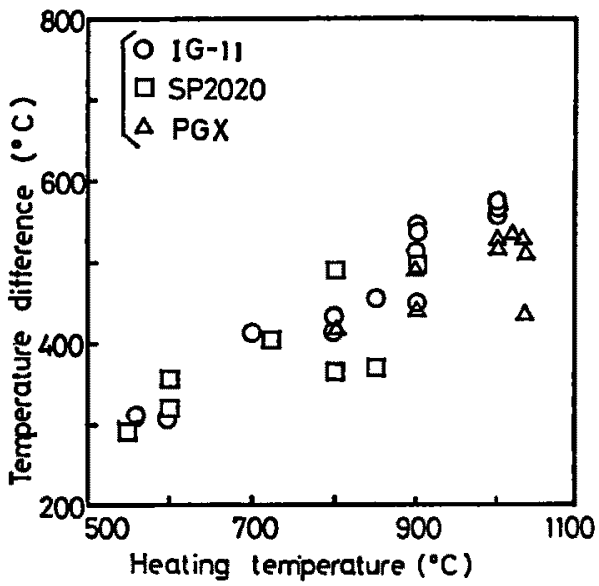

Fig. 7 Relation of maximum temperature difference between two measuring points, $r=0$ and $25 \mathrm{~mm}$, with heating temperature

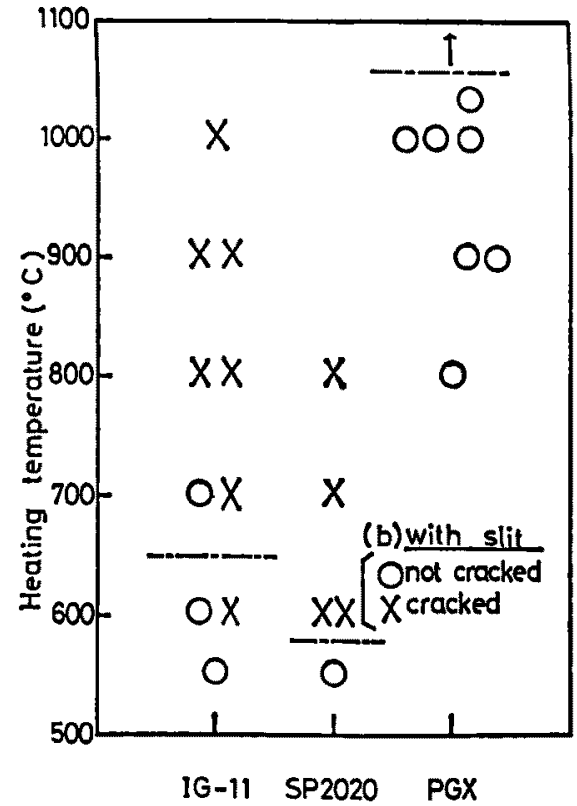

Fig. 8 Results of water quenching tests 


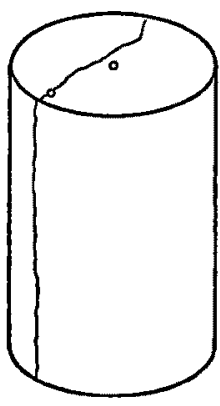

(a) 1G-11. with out slit tesled at $900^{\circ} \mathrm{C}$

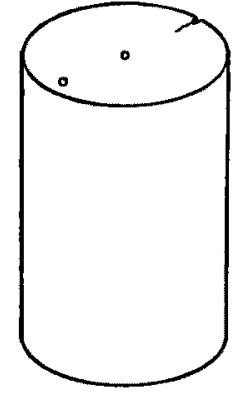

(b) IG-il with slit tested al $600^{\circ} \mathrm{C}$
Fig. 9 Schematic of specimens cracked in water quenching tests

\section{IV.考察}

\section{1. 切久き感度の比较}

Fig. 3 に示したよらに，単軸引張り応力状態におけ る切欠き感度は切欠き先端曲率半径が小さくなるにつ れて低下した。これは黑鉛が多孔筫材料であり，その 気孔寸法より小さな场久きに対しては感受性が小さく なるためと考えられる。IG-11 と PGX の黒鉛粒径は それそれ䄪0.02，0.7 $\mathrm{mm}$ であり，気孔寸法むこれに対 応している。IG-11の切欠き感度係数が PGXよりも 低曲率半经側まで大きいのはこのためと思われる。

\section{2. 圧摍破墙モード}

压樎灾力負荷時の破壤モードは IG-11 と PGXで 異なっていた。IG-11で認められた綎割れ破壊は Greenstreet らが AGOT 黑鉛についてで，PGXで認め られた新断破壤は Taylor らが等方性原子炉用黑鉛に つで㫜それぞれ報告している。

綎割れ破壊の機構について Greenstreet らは圧縮時 に発生する負荷方向に垂直な昰が引張り破断稆に達す ることを挙げている。これによれば，切欠きが存在し て引㲀り方向に応力集中が生ずる条件では，王絔破断 強度が低下することが期待される。しかし，今回の試 験において，横スリットを入れた試験片の破断強度は 平滑試験片に比して低下したが，糋スリットを入れた 試験片の破断强度は平滑試験片と有意の差は認められ なかった。また，横スリットを入れた試験片の中です， 引張り方向の応力集中が大きいと考えられる先端曲率 半径の小さな武験片での破断强度の低下は小さく，む しろ先端曲率半径の大きな試験片の破断強度の低下か: 大きかった。

先端曲率半径の大きな横スリットの効果は, PGX においても莮断破面の位膡の相違として認められる
(破断强度についてる低下傾向が認められるがごくか ずかで有意の差とは確認できい)。前述のように, 先端曲率半径の大きな横スリット試験片ではスリット 側面から整断破壊が生じている。これらのことから IG-11の横スリットによる破断強度の低下は，負荷 方向に垂直な引張り応力の集中によるすのではなく， スリット側面での圧箖応力の集中による剖断破壤に起 因寸ると考えられる。

スリット先端からの艇割れは切欠き先端曲率半径の 小さい試験片で認められたが，これらは破断強度を低 下させるに至っていない。このことは，IG-11の代縮

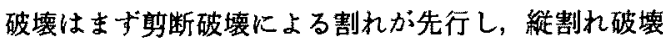
はその割れ先端か、ら発生していることを示唆してい る。今回の試験片形状では，荷重面における試験機と の摩摖力が，綎割れ破罣の場合の横力向の变位を抑制 寸る方向に働くと考壳られ，上記の破断モードを示し た一つの要因となっていると思われる。

\section{3. 熱街整破塄热抗の比較}

無限長さの円筒の外周を急冷する時に円周に発生す る最大応力は次式により表わされる(9)。

$$
\sigma_{\operatorname{maxI}}=\frac{\alpha E \Delta T}{(1-\nu)} \cdot \frac{1}{\{2.0+4.3 / \beta-0.5 \exp (-16 / \beta)\}}
$$

ここで， $\sigma_{\mathrm{maxI}}$ ：烸限円筒での最大発生応力

$$
\begin{aligned}
& E \text { : ナング率， } \Delta T \text { ：急冷温度差 } \\
& \text { レ：ポフンン比， } \alpha \text { : 熱眀脹率 } \\
& \beta \text { : ビオ数 }(=a h / k) \\
& a \text { ：試料半径， } h \text { ：熱伝達率 } \\
& k \text { : 黒鉛熱伝尊率 }
\end{aligned}
$$

Table 3 には，各黑鉛銘柄の熱膨脹率 $\alpha$, ヤング率 $E$ 拉よび引張り强度 $\sigma_{u}$ を示す。ビオ数 $\beta$ ，ポフンン比 レが黒鉛銘柄にあまり依存しないとした時，熱衝暂破 掖抵抗係数 $R\left(=\sigma_{u}(1-\nu) / E \alpha\right)$ は Table 3 に示すよ らになる。これによれば，熱衝整破壊抵杭係数が最も 高いのは SP 2020であり，次いで IG-11, PGX の順と なる。しかしこれは今回の実験で得られだ結果とは 一致しない。これは以上の考案が試験片が有している スリットや小孔等の効果を考虑していないためと思わ れる。これらを考感した場合の発生応力 $\sigma_{\max }$ は次式 で表わされる。

$$
\begin{aligned}
& \sigma_{\max }=\sigma_{\operatorname{maxI}} \cdot K \cdot S \cdot C \\
& こ こ て ゙, \quad K: \text { 态力果中係数 } \\
& S: \text { 切久き感度保数 } \\
& C: \text { 切久き位置補正保数 }
\end{aligned}
$$

したがって 
Table 3 Physical properties of graphite materials

\begin{tabular}{|c|c|c|c|}
\hline & PGX & IG-11 & Stackpole 2020 \\
\hline Coeff. thermal expansion $\alpha\left(\mathrm{RT} \sim 1,000^{\circ} \mathrm{C}\right)\left(10^{-8} /{ }^{\circ} \mathrm{C}\right)$ & 3.7 & 4.7 & 3.8 \\
\hline Young's modulus $E\left(10^{5} \mathrm{~kg} / \mathrm{cm}^{2}\right)$ & 0.64 & 1.09 & 0.92 \\
\hline Ultimate tensile strength $\sigma_{u}\left(\mathrm{~kg} / \mathrm{cm}^{2}\right)$ & 71 & 254 & 280 \\
\hline T.S.F.R. parameter $R^{\dagger}\left({ }^{\circ} \mathrm{C}\right)$ & 255 & 421 & 681 \\
\hline \multicolumn{4}{|l|}{ [for $0.5 \mathrm{~mm}^{\mathrm{R}}$ notch] } \\
\hline Notch sensitivity $S$ & 0.40 & 0.73 & - \\
\hline T.S.F.R. parameter with notch $R_{n}{ }^{\dagger}\left({ }^{\circ} \mathrm{C}\right)$ & 637 & 577 & $\longrightarrow$ \\
\hline
\end{tabular}

+ Thermal shock fracture resistance parameter, $R=\sigma_{k}(1-\nu) / E \cdot \alpha$. The value of poisson ratio $\nu$ is assumed to be 0.15 .

$+R_{n}=R / S$

$$
\begin{aligned}
\Delta T & =\frac{\sigma_{\max }(1-\nu) F(\beta)}{\alpha E \cdot K \cdot C \cdot S} \\
F(\beta) & =2.0+4.3 / \beta-0.5 \exp (-16 / \beta)
\end{aligned}
$$

残念ながら本実験の陚験片形状についての $K$ とを 正確に求めることはできなかったか，Sについては切 欠き先端曲率半径によりほぼ決定されることから， IG-11 と PGX については Fig. 3により推定が可能で ある。そこで切欠きがある場合の熱衝整破垻热抗係 数 $R_{n}$ を $R_{n}=R / S$ として, 先端曲率半径 $0.5 \mathrm{~mm}$ の切欠 きについて試算した。この時 PGX についてはFig. 3 の破線の曲線を用いた。結果はTable 3に示したが, $\mathrm{PGX} の R_{n}$ は IG-11 よりあ大きくなり, 切久き部の応 力集中を考虑した時の熱衝撃破壊抵抗は IG-11より も PGX の方が高くなることを示している。

Table 3 の数値は物性值の温度依存性や切欠き感度 伱数のとり方など，さらに検討すべき点は多いが，実 験結果を定性的に説明するるのである。IG-11と PGX のRの比率は約 1.65 である。IG-11と PGX のSの比

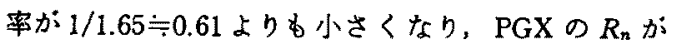
IG-11のそれよりあ大きくなるのは，Fig. 3より切久 き先端曲率半径が約 $1.0 \mathrm{~mm}$ 以下の切欠がある場合 と推定される。

\section{V. 結 論}

高温ガス実験如の有力候補黒鉛銘柄である IG-11 PGX について切久き感度を調へ，以下の結論を得た。

（1）単軸引張り应力状態における切久き感度は切
欠き先端の曲率半径がささくなるつれて低下 した。

(2) IG-11はPGXに比して高い切欠き感度を示 した。

(3) 単軸圧縮応力による PGX の破髙は応力方向 沉30 40 $0^{\circ}$ 傾斜した面内での顡断破䘫であっ た。一方，1G-11では勯断破壤と，応力力向に 平行な程割九破猿との涅合形態を示した。

(4) IG-11 の王樎破壊は新断破壊が先行し，これ に起因して縫割れ破壊が起きると推定される。

(5) IG-11 の熱衝揧破壊抵抗は PGX よりる本来 高いと考えられるが，先端曲率半径の小さな切 久きを有する場合，切欠き感度を考虑した熱衝 揧破壊抵抗はPGXよりも低くなる場合がある。

\section{一克文献—}

(1) Nightingale, R.E.: "Nuclear Graphite", (1962), Academic Press.

(2) PRICE, R.J.: $G A-A$ 13524, (1975).

(3) Brocklehurst, J.E.: TRG Rep., 2731 (s), (1976).

(4) Peterson, R.E.: "Stress Concentration Factors", (1974), John Wiley \& Sons.

(5) TUCKer, M.O.: IAEA Technical Committee Mtg. on Mechanical Behaviour of Graphite for High Temperature Reactors, Gif sur Yvette, France, (1979).

(6) Lanza, F., Burg, H.: 11th Biennial Conf. Carbon, 223 (1973).

(7) GREENSTREET, W.L., SMITH, J.E., YAHR, G.T.: Carbon, 7, 15 (1969).

(8) TAYLOR, R., et al.: ibid., 5, 519 (1967).

(9) 中山汻, 阿部弘: 材料, 32,683 (1983). 